\title{
ISLAMIC STATE AND RESHAPING THE MIDDLE EAST: WAR ON TERRORISM
}

\begin{abstract}
A war on terrorism was verbally declared by US President G.W. Bush on 11 September 2001. This declaration was a response to the terrorist attacks on the World Trade Center and Pentagon. The crash of the two planes, people throwing themselves from the burning towers, the smoke and the panic evoked enormous emotions. It highlighted shortly afterwards the distinction between the "us" and "them". "Every nation, in every region, now has a decision to make. Either you are with us, or you are with the terrorists. From this day forward, any nation that continues to harbor or support terrorism will be regarded by the United States as a hostile regime" (Bush, 2001). In this communication we will argue that the speeches on terrorism, which have been part of American politics for a long period of time, are finding their place in the Middle East. The emergence of Daesh reframed the speeches in this part of the world and created a new terminology of modern Islam, real Islam, etc. These speeches became the way that leaders of countries use to justify their participation in the war against this entity. Among these countries is Jordan. In this paper, we will focus on the construction of identities of "us" and "them" used in the propaganda of Daesh and the speeches of king Abdullah II especially after the horrible death of the Jordanian Pilot Muath Al Kassassbeh using the Critical Discourse Analysis Methods.
\end{abstract}

\section{Key words}

Daesh, Middle East, Terrorism, Islam, Jordan, Critical Discourse Analysis

* Haneen Abudayeh, assistant professor, University of Jordan, Faculty of Foreign Languages, Department of French Language and Literature. e-mail: haneendah@hotmail. com. 